\title{
ANTECEDENTS IN INFLUENCE OF UNIVERSITI MALAYSIA KELANTAN STAFF JOB PERFORMANCE
}

\author{
MOHD HAFIZUDDIN HIEW ABDULLLAH, AL-ARABI MOHAMED, MUHAMAD \\ NASYAT MUHAMAD NASIR, MUHAMMAD RIDZUAN CHE HASSAN, RAZLI \\ CHE RAZAK
}

\begin{abstract}
:
Purpose - The purpose of this paper is to test some antecedents that influence Universiti Malaysia Kelantan Staff Performance.

Design/methodology/approach - A research model based on questionnaire gleaned from the literature was used to collect data through a purposive sampling technique, whereby only those who are working in Universiti Malaysia Kelantan were targeted. The data collected were analysed using structural equation modelling technique with the use of partial least squares approach.

Findings - Results show that two out of three antecedents are significant predictors for influencing Job Performance. This paper provides further evidence on the Assement Questionnaire of Dr Talcott Parsons, Dr.Shamim and other related researchers.

Research limitations/implication - First, this study cannot be generalized to all other organizations, as the respodents are confined to local university staffs and education industry. Therefore, the results cannot be generalized to organization in other industries. Second, the study is carried out in a relatively new university with lacking of advanced facilities and only a single organization, which is Universiti Malaysia Kelantan in this case. As such, the research neds to be replicated to examine the robustness of the findings across a wider range of organization and samples.

Practical Implication - The findings suggest that Job Performance appears to be influenced by Training and Organization Culture but not Working Environment. In a relatively new university, working environment effect is a little bit lower than those two another. This show that a solid training and organization culture might help in pushing up Job Performance even the another contributing factor, working environment is sub-par in a new workplace with lack of facilities and support. Anyway, it is vital for increases working environment in order to keep track of other far better education institution with full facilities and comfortable workplace if Universiti Malaysia Kelantan is looking to be one of the top local universities.

Originality/value - This paper adds to the existing literature of Job Performance in a relatively new organization setting. Although there has been some research on the same issue, but it is more on a well-established organization and mostly not education industry.
\end{abstract}

\section{Keywords:}

Malaysia, University, Job Performance, Organization Culture, Working Environment, Training

JEL Classification: C12, 123, M10

\section{Authors:}

MOHD HAFIZUDDIN HIEW ABDULLLAH, Universiti Malaysia Kelantan, Malaysia, Email: 
hiewhafizuddin@gmail.com

AL-ARABI MOHAMED, Universiti Malaysia Kelantan, Malaysia, Email: hafizarabi@gmail.com MUHAMAD NASYAT MUHAMAD NASIR, Universiti Malaysia Kelantan, Malaysia, Email:

hiewhafizuddin@gmail.com

MUHAMMAD RIDZUAN CHE HASSAN, Universiti Malaysia Kelantan, Malaysia, Email:

hiewhafizuddin@gmail.com

RAZLI CHE RAZAK, Universiti Malaysia Kelantan, Malaysia, Email: hiewhafizuddin@gmail.com

\section{Citation:}

MOHD HAFIZUDDIN HIEW ABDULLLAH, AL-ARABI MOHAMED, MUHAMAD NASYAT MUHAMAD NASIR, MUHAMMAD RIDZUAN CHE HASSAN, RAZLI CHE RAZAK (2016). Antecedents in Influence of Universiti Malaysia Kelantan Staff Job Performance. International Journal of Business and Management, Vol. IV(2), pp. 1-18., 10.20472/BM.2016.4.2.001 


\section{Introduction}

From year to year since Malaysia Merdeka, Malaysia has made positive progress in education system on various aspects including increased access to pre-school education and secondary education, as well as expanded opportunities to pursue postsecondary and tertiary education. Measures taken to address inequities in the system, including special programmes for the indigenous population, support programmes for poor students, and the focus on narrowing the gap between rural and urban populations by upgrading and expanding educational facilities and deployment of more qualified teachers, have produced tangible results. One of the major factors in those tangible results is of course, the increases of workforce quality and performance. In education system, workforce mainly divided into two major categories: the administrative staff and also the education staff. Both staff involving directly in students' enhancement as well as skill development. Hence, staff performance and development is always considered one of the major factors in the success of education system in Malaysia.

According to macro point-of-view, the theory of economic growth states that human capital accumulation gives important contribution to economic growth, and to micro point-of-view, human resource theory considers human capital as the primary source for sustainable competitive advantage for the organization (Koentjaraningrat, 2004).

According to Ninth Malaysia Plan 2006-2010 (2006), The Universiti Malaysia Kelantan (UMK; English: University of Malaysia, Kelantan) is a 19th public university in Kelantan, Malaysia. The formation of the university was mooted during the tabling of the Ninth Malaysia Plan and approved by the cabinet of Malaysia on 14 June 2006. The launching ceremony was held at the end of 2006 by Prime Minister, Y.A.B. Tun Abdullah Ahmad Badawi. We choose this University as our survey place because of this is a new university hence it is understandable that the working environment, training and organizational culture might be not as good as the established university, so this is a relatively good study to determine the factors affecting job performance. The working department of a public university mainly consists of educational staff and administration staff, with unique job responsibility but some similarity, but all in all is to building up a better education system in a team. Hence job performance from either department will surely contributing directly on education development in the university.

Normatively, the study of human resource management consists of two approaches, namely Harvard's approach and Michigan's approach. The first approach is known as the software version of human resource management, emphasizing that the commitment of staff is the primary driven factor to compete and to achieve the organization goals. Accordingly, this factor gains many attentions from stakeholders. The second approach is known as the hard version, emphasizing the capital resource and the human resource itself. This approach addresses the suitability of internal fit in the practice of human resource and external fit in the practice of human resource and the management strategy. This strategic point-of-view is known as human resource management strategy (Delery and Doty, 1996). 
Interpersonal relationships within the organization will be effective if supported by organization environment that will ensure the success of organizational activities. Organization environment requires a conducive working environment which associated with physical and psychosocial factors of a working employee. It is similar to Allen (2001) who stated the effect of working environment to organizational behaviour could be either positive or negative.

According to Dr. Marshall Sashkin, et.al (2013), Long term organizational survival depends on how well the efforts of individuals and groups within the organization are tied together, coordinated and sequenced so that people's work efforts fit together effectively. Organizational Culture is one of the key element for boasting job performance as it is more acting as an emotional enhancement among the staff.

The next Section of this paper discusses the theoretical foundation. This is followed by an explanation of the research model and the hypotheses. Next, the method used is described before the findings are covered. This includes an assessment of goodness of measures, namely, construct validity, convergent validity, discriminant validity and reliability of the constructs. Subsequent sections deal with discussion, implications, limitations and conclusions.

\section{Theoretical foundation}

The antecedents that influencing the job performance of the workers have been widely studied across a broad spectrum of industries. The main objective of every organization is to improve its performance but it can never be possible without the efficient performance of employees. Therefore, the performance management system came into effect as a management reform to address and redress concerns, organizations had about performance (Sharif, 2002). In its effort to enhance the job performance of employees, many initiatives have been taken into account like training and development. Therefore, in addressing this matter pertaining job performance, it is necessary for researcher to determine the factors that affect the employee job performance.

The foundation of the theory that relevant to this study includes the theory of organizational culture, working environment and training which all are certainly needed in a local university. Those supporting theories were taken from some researches such as Armstrong, Bacal, Beer, Chatman and John, Dubrin, Davis and Newstrom, Dessler, Drucker, Fletcher, Gomes, Gibson, and Malthis. A short description of each of the constructs is presented below.

\section{Organization Culture}

Culture is often defined as system of shared understandings, values, and norms (DiMaggio, 1994, p. 27). It is passed on from one generation to the next and between individuals by a variety of alternative transmission channels. Path dependence, differences in the environment and related aspects may lead to unequal cultural traits in different regions of the world. It is also a well-documented fact that culture changes over time (see, e.g. Inglehart et al., 1998; Inglehart and Welzel, 2005). Examples for 
cultural differences are abundant, but not all of them seem relevant for the organization of economic institutions. The culture of an organization is crystallized and reformed continuously and dynamically over time. It is a set of shared assumptions (Schein, 1992) about the world of work within a particular profession. These assumptions relate to concepts such as reality, truth, time and space as these impinge on individuals and groups.

\section{Training}

Elnaga and Imra (2013) posit that to develop the desired knowledge, skills and abilities of the employees, to perform well on the job, requires effective training programs that may also effect employee motivation and commitment. Elnaga and Imra (2013) further argue that in order to prepare their workers to do their job as desired, organizations provide training so as to optimize their employee's potential. Goldstein (1980) defined training as "the acquisition of skills, concepts, or attitudes that results in improved performance in an on-the-job environment". Armstrong (1995) argues that on-the-job training may consist of teaching or coaching by more experienced people. He added that it is the only way to develop and practice the specific managerial and administrative skills needed by the organizations. For instance, when apprentices have completed academic and vocational training programs successfully, they can proceed to on job training. In a research conducted by Bartel (1995), he found that formal training (on-the job training) does indeed increase wage growth and job performance, even when selection bias in assignment to training programs is eliminated. Meanwhile, off-the-job training is the training that occurs away from the workplace and consists of internal or external programs to develop a variety of skills or to foster personal development (Nickels et al, 2002). Off-the-job training may focus on the classroom, with lecturers, seminars, and films, or it may involve 'computer-assisted instruction' (CAI), which can both reduce the time needed for training and provide more help for individual trainees (Dosset and Hulvershorn, 1983; Schwade, 1985; Heck, 1985). These tend to influence employees' performance and organizational competitiveness.

\section{Working Environment}

One of the fundamental human requirements is a working environment that allows people to perform their work optimally under comfortable conditions. Working environment in some ways have been a part of factors that may influence the individual job performance of an organization. In a survey conducted by the Building Owners and Managers Association International (BOMA, 1988) in the US, it revealed that the indoor environment like sound level, lighting, air quality and thermal environment in particular is regarded as a major problem within the scope of building management, maintenance and design. The respondents also voiced their expectation that improving theindoor environment would lead to a significant rise in productivity in the organisation. Dorgan (1994) defines productivity as the increased functional and organisational performance, including quality. An increase in performance is expressed in a directly quantifiable 
reduction of absenteeism, such as a reduction in the number of employees that leave work too early or take long lunch breaks. The improvement in performance can, however, also be the result of an increase in the quantity and the quality of the production during the period that employees are actively working.

\section{Job Performance}

Brown (2008) defines performance as how well a person completes tasks and also the attitude with which he/she completes the tasks. Employee performance is normally looked at in terms of outcomes. However, it can also be looked at in terms of behaviour (Armstrong 2000). However, according to Hersen (2004), job performance can be defined (and assessed) in terms of quantifiable outcomes of work behaviours such as amount of sales, numbers sold and also in terms of behavioural dimensions which may include work-related communication, decision making, problem solving among other skills.

\section{Research model}

This study is to understand the influence of various perceived attributes on the Universiti Malaysia Kelantan staff job performance. The research model in Figure 1 was developed based on the above mentioned literature studies.

Figure 1. Research Framework

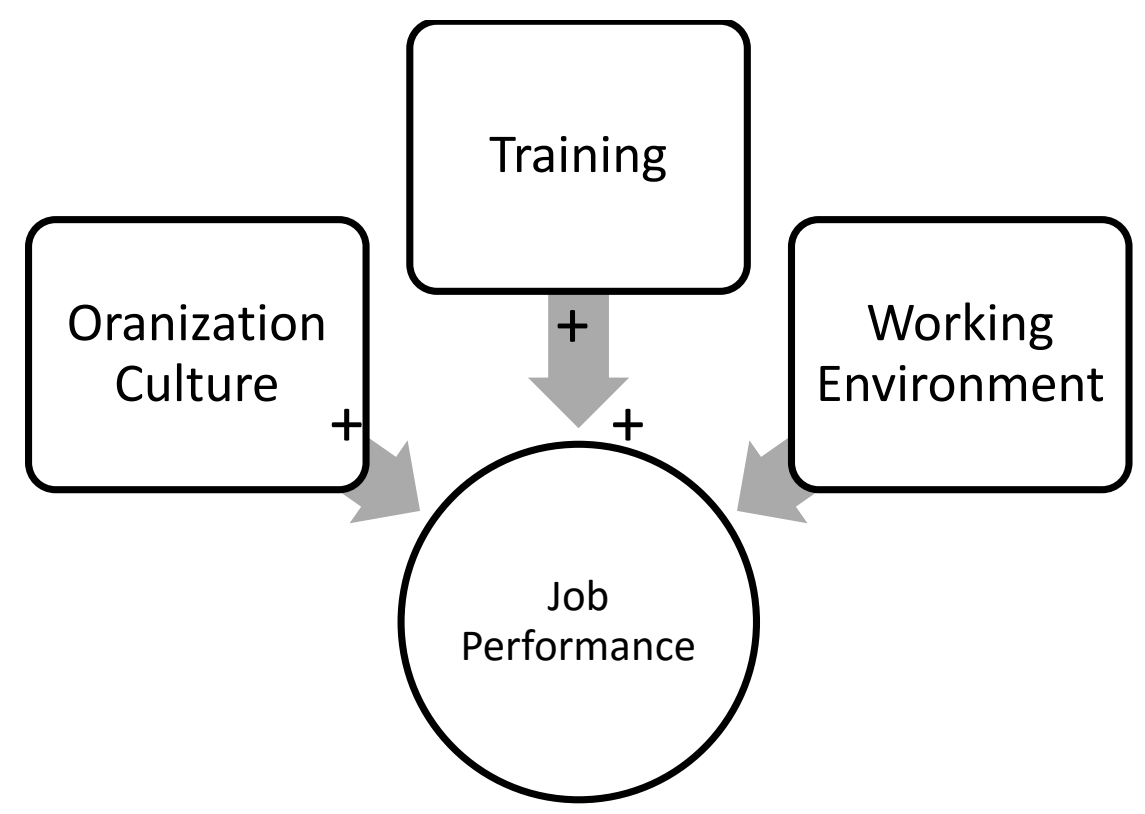

Hypotheses development

Olaniyan and Lucas (2008) believe that training enhances the employees' capacity to contribute the optimal performance of the organization. Meanwhile, Clements-Croome, D. (1997) has yielded that by improving work environment, it can reduce the number of complaints and absenteeism and thus increase the productivity. Thus, this leads to the following hypothesis: 
H1. Perceived organization culture is positively related to job performance

H2. Perceived training is positively related to job performance

H3. Perceived working environment is positively related to job performance

\section{Research methodology}

The study population comprises Administration Staff and Education Staff who are working in the local university, namely, Universiti Malaysia Kelantan. A purposive sampling technique was employed. The reason for choosing this university is to investigate how job performance is effected in a relatively new working environment. To obtain the data, 100 individuals were selected to participate in the survey. The initial questionnaire was passed to all the potential respondents department and included was a request that the respondent department will ask and distributed the survey to the respondents. To ensure meaningful data are collected, each respondent was required to acknowledge that he or she has basic English language reading skills before completing the questionnaire.

Although 100 questionnaires were distributed, only 90 were received while 10 were lost due to the department technical error. Among the 90,8 of these were rejected due to error in completing sections of questionnaire. Therefore, only a sample size of $N=81$ was used for this study giving a high response rate of 81 percent. Data were collected using a questionnaire which used a five-point Likert scale response format. Survey items were developed from a review of the literatures. Very minimal changes were made to the final version of the questionnaire.

\section{Findings}

The demographic profile of the respondent is presented in Table I. There was a dominate of female staff than male, with a majority having Tertiary Education, although majority are relative young which are below 31 years old, with less than 6 years working experience. 18 out of 81 respondents are Academic Staff while 63 of them are Administrative staff.

To access the model, we used Smart-PLS M3.2.3 to estimate the parameters in the outer and inner model. PLS tries to maximize the variance explained of the dependent variables. Applications of statistical methods have expanded dramatically with the advent of computer hardware and software, particularly in recent years with widespread access to many more methods due to user-friendly interfaces with technology-delivered knowledge, and Smart-PLS M3 2.3 is one of those, and is invented Joseph F. Hair. Jr. It offers many benefits with respect to distribution requirement, type of variables, sample size and complexity of the model to be tested (Ringle et al., 2005). We applied PLS path modelling with a path-weighting scheme for the inside approximation (Chin, 1998). Then, we applied the nonparametric bootstrapping approximation (Chin, 1998) with 500 resampling to obtain the standard errors of the estimates. 
Table I. Demographic profile of respondents

\begin{tabular}{llcr}
\hline Variables & Category & Frequency & $\%$ \\
\hline Gender & Male & 28 & 34.6 \\
Age (in years) & Female & 53 & 65.4 \\
& $21-25$ & 20 & 24.7 \\
& $26-30$ & 33 & 40.7 \\
& $31-35$ & 8 & 9.9 \\
& $36-40$ & 9 & 11.1 \\
& $41-45$ & 10 & 12.3 \\
Marital Status & 46 and above & 1 & 1.2 \\
Education & Single & 44 & 54.3 \\
& Married & 37 & 45.7 \\
& SPM & 8 & 9.9 \\
& Diploma & 21 & 25.9 \\
Job Type & Bachelor degree & 39 & 48.1 \\
& Master degree & 11 & 13.6 \\
Work Tenure (in & PhD & 2 & 2.5 \\
years) & Academic & 18 & 22.2 \\
& Administrative & 63 & 77.8 \\
& $1-5$ & 48 & 59.3 \\
& $6-10$ & 18 & 22.2 \\
& $11-15$ & 11 & 13.6 \\
& $16-20$ & 3 & 3.7 \\
& 20 and above & 1 & 1.2 \\
\hline
\end{tabular}

\section{Assessment of the measurement model}

First we tested convergent validity which is the degree to which is the degree to which multiple items measuring the same concept are in agreement. As suggested by Hair et al. (2010) we used the factor loadings, composite reliability and average variance extracted to assess convergence validity. The loadings for all items exceeded the recommended value of 0.5 (Hair et al., 2010). Composite reliability values (see Table II), which depict the degree to which the construct indicators indicate the latent construct ranged from 0.902 to 0.929 which exceeded the recommended value of 0.7 (Hair et al., 2010). The average variance extracted, which reflects the overall amount of variance in the indicators accounted for by the latent construct, were in the range of 0.512 to 0.766 which exceeded the recommended value of 0.5 (Hair et al., 2010).

\section{Discriminant validity of constructs}

Next we proceeded to test the discriminant validity. Discriminant validity is the extent to which the measures is not reflection of some other variables and is indicated by the low correlations between the measure of interest and the measure of other constructs (Cheung and Lee, 2010). Discriminant validity can be examined by comparing the 
squared correlations between constructs and the average variance extracted for a construct (Fornell and Lacker, 1981). As shown in Table III, the squared correlations for each construct is less than the average variance extracted by the indicators measuring that construct indicating adequate discriminant validity. In total, the measurement model demonstrated adequate convergent validity and discriminant validity.

Assessment of the structural model

We then evaluated the structural model to test the hypotheses. As shown in Figure 2 and Table IV, all of the hypotheses were supported. Organization Culture (Beta Coefficient, $\beta=0.284$, Calculated probability, $\rho=0.034, \rho<0.05$ ) and Training (Beta Coefficient, $\beta=0.393$, Calculated probability, $\rho=0.009, \rho<0.01$ ) were all positively related to job performance while Working Environment (Beta Coefficient, $\beta=0.393$, Calculated probability, $\rho=0.009, \rho<0.01$ ) was not positively related to job performance. Thus $H 1$, and $H 2$ were supported while $H 3$ was not supported. The variance explained for each model is given in Figure 2 and Table IV. 
Table II. Result of the measurement model

\begin{tabular}{|c|c|c|c|c|c|}
\hline Constructs & Code & Loadings & $\alpha$ & CR & AVE \\
\hline Organization & OC1 & 0.718 & 0.881 & 0.904 & 0.512 \\
\hline \multirow{8}{*}{ Culture } & OC2 & 0.778 & & & \\
\hline & OC3 & 0.714 & & & \\
\hline & OC5 & 0.692 & & & \\
\hline & Oc6 & 0.817 & & & \\
\hline & OC7 & 0.589 & & & \\
\hline & OC8 & 0.728 & & & \\
\hline & OC9 & 0.709 & & & \\
\hline & OC10 & 0.670 & & & \\
\hline \multirow[t]{6}{*}{ Training } & CT1 & 0.831 & 0.870 & 0.902 & 0.607 \\
\hline & CT2 & 0.797 & & & \\
\hline & СТ3 & 0.729 & & & \\
\hline & CT4 & 0.830 & & & \\
\hline & CT7 & 0.705 & & & \\
\hline & СТ8 & 0.774 & & & \\
\hline Working & WE1 & 0.809 & 0.884 & 0.909 & 0.559 \\
\hline \multirow[t]{7}{*}{ Environment } & WE2 & 0.820 & & & \\
\hline & WE3 & 0.800 & & & \\
\hline & WE4 & 0.803 & & & \\
\hline & WE5 & 0.719 & & & \\
\hline & WE6 & 0.720 & & & \\
\hline & WE7 & 0.755 & & & \\
\hline & WE9 & 0.505 & & & \\
\hline \multirow[t]{4}{*}{ Job Performance } & JP1 & 0.893 & 0.898 & 0.929 & 0.766 \\
\hline & JP2 & 0.873 & & & \\
\hline & JP3 & 0.879 & & & \\
\hline & JP4 & 0.855 & & & \\
\hline
\end{tabular}

Notes: $\alpha$, Cronbach's alpha; CR, composite reliability; AVE, average variance extracted; OC4, CT5, CT6, CT9, CT10, WE8 and WE10 were deleted due to low loadings

\section{Table III. Discriminant validity of constructs}

\begin{tabular}{lcccc}
\hline & 1 & 2 & 3 & 4 \\
\hline 1. Job Performance & 0.875 & & & \\
2. Organization Culture & 0.664 & 0.715 & & \\
3. Training & 0.697 & 0.756 & 0.779 & \\
4. Working Environment & 0.610 & 0.691 & 0.745 & 0.748
\end{tabular}

Note: Diagonals are the AVE while the off-diagonal are the squared correlations 


\section{Figure 2. Structural Model}

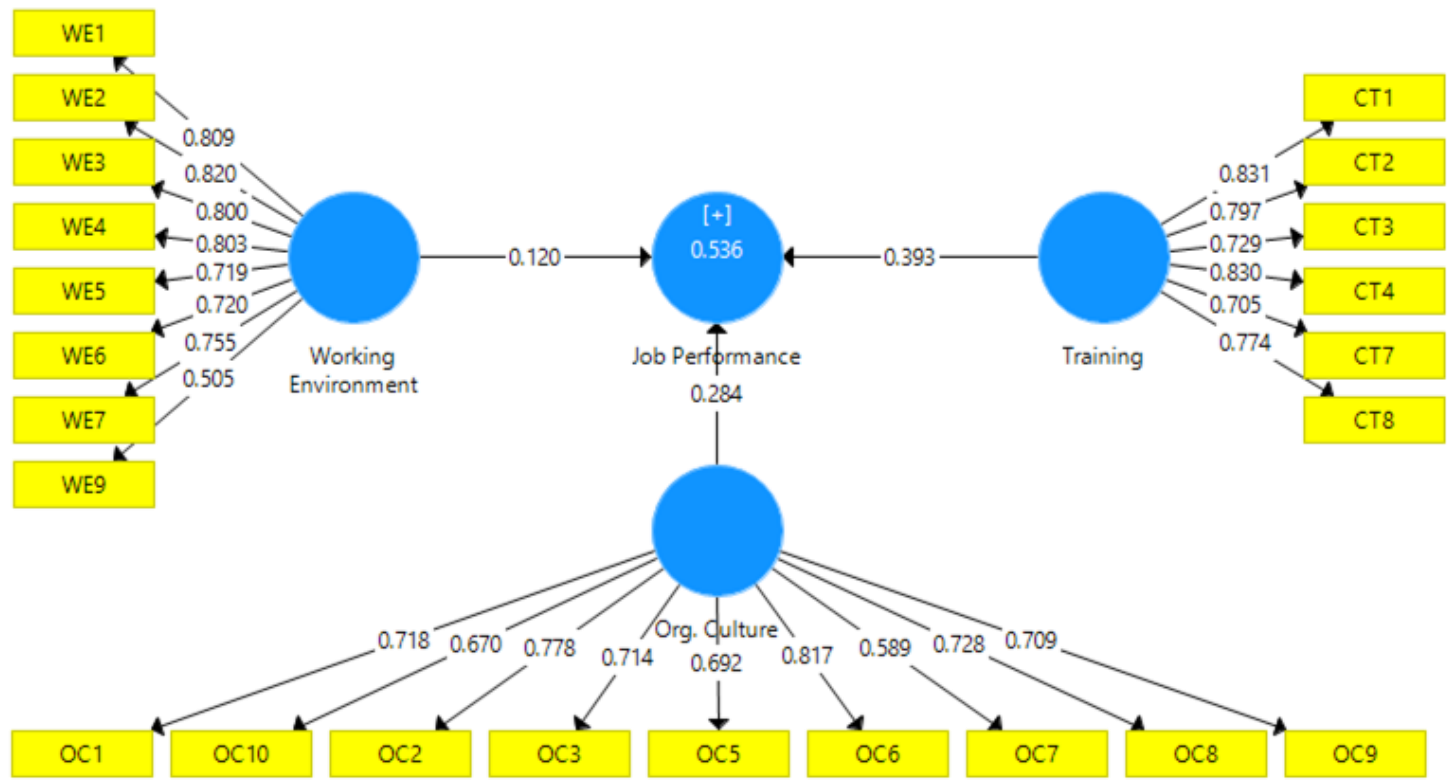

Notes: ${ }^{* *} \mathrm{P}<0.01 ;{ }^{*} \mathrm{P}<0.05$

Table IV. Path coefficients and hypothesis testing

\begin{tabular}{lccccl}
\hline \multicolumn{1}{c}{ Path } & Original & Standard & t-Statistics & P Values & Decision \\
\hline $\begin{array}{l}\text { H1 Org. Culture } \rightarrow \\
\text { Job Performance }\end{array}$ & 0.284 & 0.134 & 2.126 & $0.034^{*}$ & Supported \\
$\begin{array}{l}\text { H2 Training } \rightarrow \text { Job } \\
\begin{array}{l}\text { Performance } \\
\text { H3 Working }\end{array}\end{array}$ & 0.393 & 0.150 & 2.618 & $0.009^{* *}$ & Supported \\
$\begin{array}{l}\text { Environment } \rightarrow \text { Job } \\
\text { Performance }\end{array}$ & 0.120 & 0.122 & 0.987 & 0.324 & $\begin{array}{l}\text { Supported } \\
\text { Perman }\end{array}$ \\
\hline
\end{tabular}

Notes: Original is the initial path coefficient while Standard is the Standard Deviation after ootstrapping.

\section{Discussion, implication, limitation and conclusion}

Organization Culture was hypothesized to be positively related to job performance. This study found that the hypothesis was supported. It can be argued that the job performance can be boasted with positive organization culture included clear goal setting, good team working, and established working policy. Hofstade (2005) stated without exception, the culture has a very strong relation and be a major factor in the success of an organization.

Training was also hypothesized to be positively related to job performance. This study found that the hypothesis was supported. Training is perceived by Elnaga and Imra (2013) as an important antecedent in maximize workers' potential and hence increases job performance in the long run. This observation is similar to the result of many previous studies included Goldstein (1980), Bartel (1995) and Nickels et. al. (2002) which have consistently found that job training to be a factor influencing job performance. Training 
shows the highest path coefficient among all attendances for this study, showing that Universiti Malaysia Kelantan has a relatively strong external and internal training.

Working Environment was hypothesized to be positively related to job performance. This study found that the hypothesis was not supported. It can be argued that while working environment is important for job performance in most organizations, Universiti Malaysia Kelantan might not really depend on it as it is still a relatively new university with a lot of shortage in resources and lack of facilities, and hence making all staff in the equally same situation of lacking of desired working environment and they forced to adapted it. Aguinis (2009) had described job performance is about the behaviour or what employees do, not about what employees produce or the outcome of their works, while employees' performance may be taken in the perspective of three factors which makes possible to perform better than others, determinants of performance maybe such as "declarative knowledge", "procedural knowledge", and "motivation" (McCloy et al., 1994). When we further divided the finding into two major groups (see Table $V$ and Table VI), namely administrative staff and academic staff, we figured out that it is the same for either group of workforce in term of the strongest attendances, and both $P$ values of the $\mathrm{H} 3$ are higher than 0.05 respectively, hence showing this $\mathrm{H} 3$ is not supported by both groups of respondents.

Table V. Path coefficients and hypothesis testing (only academic staff involved)

\begin{tabular}{lccccc}
\hline \multicolumn{1}{c}{ Path } & Original & Standard & t-Statistics & P Values & Decision \\
\hline $\begin{array}{l}\text { H1 Org. Culture } \rightarrow \\
\text { Job Performance }\end{array}$ & 0.153 & 0.133 & 2.125 & $0.033^{*}$ & Supported \\
$\begin{array}{l}\text { H2 Training } \rightarrow \text { Job } \\
\begin{array}{l}\text { Performance } \\
\text { H3 Working }\end{array}\end{array}$ & 0.658 & 0.595 & 3.731 & $0.000^{* *}$ & Supported \\
$\begin{array}{l}\text { Environment } \rightarrow \text { Job } \\
\text { Performance }\end{array}$ & 0.218 & 0.133 & 0.700 & 0.324 & Supported \\
\hline
\end{tabular}

Notes: Original is the initial path coefficient while Standard is the Standard Deviation after ootstrapping of the total sample of 18 academic staffs out of total of 81 respondents.

Table VI. Path coefficients and hypothesis testing (only administrative staff involved)

\begin{tabular}{lccccc}
\hline \multicolumn{1}{c}{ Path } & Original & Standard & t-Statistics & P Values & Decision \\
\hline $\begin{array}{l}\text { H1 Org. Culture } \rightarrow \\
\text { Job Performance }\end{array}$ & 0.222 & 0.260 & 2.137 & $0.033^{*}$ & Supported \\
$\begin{array}{l}\text { H2 Training } \rightarrow \text { Job } \\
\begin{array}{l}\text { Performance } \\
\text { H3 Working }\end{array}\end{array}$ & 0.605 & 0.569 & 2.817 & $0.005^{\star *}$ & Supported \\
$\begin{array}{l}\text { Environment } \rightarrow \text { Job } \\
\text { Performance }\end{array}$ & 0.174 & 0.115 & 0.645 & 0.519 & Supported \\
\hline
\end{tabular}

Notes: Original is the initial path coefficient while Standard is the Standard Deviation after ootstrapping of the total sample of 63 administrative staffs out of total of 81 respondents. 
Both academic and administrative staffs' data analysis showed that Training is the strongest factor among all three antecedents tested in influencing their job performance. It can be explained as when the working environment is not in their favour, skills and knowledge enhancement programmes will be their key dependency in order to increase their job performance. Organization Culture, as well playing a major role in diminishing the downside of working environment in boasting their job performance for either group of staffs.

\section{Implications}

This study has important Implications for both research and human resource management in university. In terms of research, this study provides further evidence on the appropriateness of using Sashkin's assessment to measure the importance of organization culture in boasting job performance. Moreover, a strong organizational culture will effect on corporate policies, organizational structure, and other rules. In the organization, the employee should know what his obligations are in various situations and conditions according to the instructions and guidelines which are reflected in the values espoused in the organization.

This study also found that Training appears to be one of the key factors in increases of job performance. On Job Training is needed not matter how senior a staff is in order to catch up the fast-paced information technology world, especially for lecturers in this information ages in order to be always in front and soaring the education level upwards and directly increases the reputation of university to be placed among the top local universities in Malaysia, and internationally at last.

Lastly, it is also figured out that in a relatively new working environment, work place comfortability and other physical constraints didn't really affect much on Universiti Malaysia Kelantan job performance. It might because of the relatively high motivation from the top management, which mostly consists of highly experience Professors and Senior workforce that transferred from other top local university. This top management group plays a vital role in building up emotional enhancement and motivation of the employees to perform well even under sub-par working environment. (McCloy et al., 1994).

\section{Contribution to theory}

The objective of this study is to identify and confirmed the three antecedents that is contributing in job performance, and it found out that working environment is not always positively related into job performance in a relatively new organization, especially an education institution which more focuses on knowledge delivery instead of physical products. McCloy et al. (1994) stated that training and motivation is one of the important factors for boasting job performance and building up organization culture. And it is proven by this study that Universiti Malaysia Kelantan might has a solid internal and external training schedule and a great top management team to motivate, monitor and 
lead the workforce to better job performance although in such a sub-par working environment in this young university.

\section{Limitations}

As with all research, this study also has certain limitations. First, this study cannot be generalized to all other individuals as the respondents are mostly in tertiary education and working in education industry. Therefore, results cannot be generalized to individuals working on other industries. As such, there is still room for further investigation into the other industries. Extending the study to include individuals working in other industries or sectors or divisions may add further support to the findings.

Second, the study was carried out in a relatively new university, which is Universiti Malaysia Kelantan in this case. As such, the research needs to be replicated to examine the robustness of the findings across a wider range of universities and samples.

Thirdly, administrative staffs are actually can be further divided into three more groups according to their Grades as each grades have different salary cap, workplace allocation as well as different training and organization. So, further research should be done into dividing it into details in order to obtain more comprehend result.

Finally, there are some possibilities of measurement errors. The study focussed on perception of the respondents and the instrument relied on self-reports and perceptions of the respondents alone. This could have resulted in some degree of perceptual inflation of self-assessment scores. Those who enjoyed great satisfaction with the university may have inflated their response with respect to their intention in working in Universiti Malaysia Kelantan. Additionally, the instrument was also self-administered and there could be situations where respondents may need further clarification, which was not available.

\section{Conclusion}

This study shown the antecedents relationship to the job performance in Universiti Malaysia Kelantan. It has shown that perceived organization culture and training influences the job performance and also determine the outcome of the employees in the new working environment while the work place condition is not really positively related into job performance although it is perceived to be positively related initially. Although these three factors are considered to be some of the most important factors in influence job performance, there are highly possibility that additional factors may influence the job performance. One of such might be the role of Top Management as moderating effect amongst all those factors which might be further investigated.

Finally, this study has provided some additional insights into the relationship between working environment and job performance in relatively new start up organization, for this study, in university. Perceived positively relationship of working environment and job performance is rejected and not supported in this study. McCloy et al. (1994) are among those who always supporting that emotional and motivational factors are more 
important than those physical requirements included working environment condition. It has confirmed McCloy's point of view in this study, when working environment is subpar in an organization, organization culture and training which focuses on building team spirit, emotional factors and motivations are playing important role in boasting employees' job performance. Thus, the findings have important implications not only for theory, but for practice as well. 


\section{Appendix}

Table Al. Questionnaire items

\begin{tabular}{|c|c|c|}
\hline Constructs & Item & Sources \\
\hline \multirow[t]{10}{*}{$\begin{array}{l}\text { Working } \\
\text { Environment }\end{array}$} & $\begin{array}{l}\text { WE1: I can perform work better when the } \\
\text { noises are at minimum level. }\end{array}$ & Wyon, D. P. (1986). \\
\hline & $\begin{array}{l}\text { WE2: Good lighting is crucial for me to work } \\
\text { productively. }\end{array}$ & Robbins, S. (1997). \\
\hline & $\begin{array}{l}\text { WE3: Air Ventilation at my workplace } \\
\text { influences my job performance. }\end{array}$ & Fanger, P. O. (1999) \\
\hline & $\begin{array}{l}\text { WE4: Suitable temperature plays a vital role } \\
\text { for me to perform my work. }\end{array}$ & Wyon, D. P. (1986). \\
\hline & WE5: Humidity at my workplace is fine for me & $\begin{array}{l}\text { Paul Roelofsen, } \\
\text { (2002) }\end{array}$ \\
\hline & $\begin{array}{l}\text { WE6: The environment around my working } \\
\text { place is clean and tidy }\end{array}$ & $\begin{array}{l}\text { Mateo, R., } \\
\text { Hernández, J. R., } \\
\text { Jaca, C., } \\
\text { Blazsek.S.(2013). }\end{array}$ \\
\hline & $\begin{array}{l}\text { WE7: It is my own responsibility to clean the } \\
\text { workplace instead of the cleaners }\end{array}$ & $\begin{array}{l}\text { Mateo, R., } \\
\text { Hernández, J. R., } \\
\text { Jaca, C., } \\
\text { Blazsek.S.(2013). }\end{array}$ \\
\hline & $\begin{array}{l}\text { WE8: My working space is more than enough } \\
\text { for my tasks }\end{array}$ & Ramstad, E. (2009). \\
\hline & WE9: I like my current office allocation & Ramstad, E. (2009). \\
\hline & $\begin{array}{l}\text { WE10: My workplace is safe and secure with } \\
\text { all safety equipment like fire extinguisher etc. }\end{array}$ & Ramstad, E. (2009). \\
\hline \multirow[t]{9}{*}{ Training } & $\begin{array}{l}\text { CT1: On-the-job training updates me to the } \\
\text { new technology use. }\end{array}$ & Barber, J. (2004). \\
\hline & $\begin{array}{l}\text { CT2: I can acquire the required skills in } \\
\text { completing tasks if I am trained in the working } \\
\text { environment. }\end{array}$ & Barber, J. (2004). \\
\hline & CT3: Off-the job training gives me early & Harris, D. M., \& \\
\hline & insight of how to perform a work. & $\begin{array}{l}\text { DeSimone, R. L. } \\
\text { (1994). }\end{array}$ \\
\hline & CT4: Undergoing training outside of office & Harris, D. M., \& \\
\hline & $\begin{array}{l}\text { enables me to require new skills to enhance } \\
\text { my performance. }\end{array}$ & $\begin{array}{l}\text { DeSimone, R. L. } \\
\text { (1994). }\end{array}$ \\
\hline & $\begin{array}{l}\text { CT5: I like the training scheduling of my } \\
\text { organization }\end{array}$ & Bakan, I. (n.a.) \\
\hline & $\begin{array}{l}\text { CT6: I prefer the training courses are all at } \\
\text { weekend }\end{array}$ & Bakan, I. (n.a.) \\
\hline & $\begin{array}{l}\text { CT7: I prefer the training courses are not } \\
\text { interrupting my personal holidays }\end{array}$ & Bakan, I. (n.a.) \\
\hline
\end{tabular}




\begin{tabular}{|c|c|c|}
\hline & $\begin{array}{l}\text { CT8: Intense training increases my working } \\
\text { performance }\end{array}$ & Aguinis, H.\& Kraiger, \\
\hline & $\begin{array}{l}\text { CT9: Training is more needed to junior staff, } \\
\text { while senior staff should be exempted }\end{array}$ & Bakan, l. (n.a.) \\
\hline & $\begin{array}{l}\text { CT10: Less training will cause performance } \\
\text { dropping }\end{array}$ & $\begin{array}{l}\text { Aguinis, H.\& Kraiger, } \\
\text { K. (2009). }\end{array}$ \\
\hline $\begin{array}{l}\text { Organization } \\
\text { Culture }\end{array}$ & $\begin{array}{l}\text { OC1: Individuals and teams have clearly } \\
\text { defined goals that relate to the goals and } \\
\text { mission of the university. }\end{array}$ & Sashkin, M. (2013). \\
\hline & $\begin{array}{l}\text { OC2: I give the highest priority and support to } \\
\text { meeting the needs of clients and customers } \\
\text { and to solve their problems. }\end{array}$ & Sashkin, M. (2013). \\
\hline & $\begin{array}{l}\text { OC3: University's policies and procedures } \\
\text { help me to provide the service our customers } \\
\text { want and need. }\end{array}$ & Sashkin, M. (2013). \\
\hline & $\begin{array}{l}\text { OC4: I often see customer and client } \\
\text { problems as someone else's responsibility }\end{array}$ & Sashkin, M. (2013). \\
\hline & $\begin{array}{l}\text { OC5: I always looking for new ways to better } \\
\text { serve clients and customers. }\end{array}$ & Sashkin, M. (2013). \\
\hline & $\begin{array}{l}\text { OC6: I believe in working together } \\
\text { collaboratively, preferring cooperation over } \\
\text { competition. }\end{array}$ & Sashkin, M. (2013). \\
\hline & $\begin{array}{l}\text { OC7: The administrative staff and educational } \\
\text { staff at all levels work together as a team to } \\
\text { achieve results for the organization. }\end{array}$ & Sashkin, M. (2013). \\
\hline & $\begin{array}{l}\text { OC8: I strongly believe in a set of shared } \\
\text { values about how people should work } \\
\text { together to solve common problems and } \\
\text { reach mutual objectives }\end{array}$ & Sashkin, M. (2013). \\
\hline & $\begin{array}{l}\text { OC9: Team working is one of my workplace } \\
\text { culture }\end{array}$ & Sashkin, M. (2013). \\
\hline & $\begin{array}{l}\text { OC10: I like my current organization culture } \\
\text { and hope to keep it this way as it is best for } \\
\text { my optimum performance }\end{array}$ & Sashkin, M. (2013). \\
\hline Job & JP1: I can make fast and rational decision & Roelofsen, P. \\
\hline Performance & with comfortable working environment. & 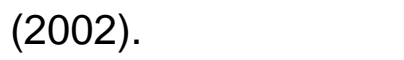 \\
\hline & $\begin{array}{l}\text { JP2: Work problems can be solved faster by } \\
\text { undergoing training. }\end{array}$ & Barber, J. (2004). \\
\hline & $\begin{array}{l}\text { JP3: Working as a team would enhance my } \\
\text { job performance }\end{array}$ & Sashkin, M. (2013). \\
\hline & $\begin{array}{l}\text { JP4: Having a clear organizational goal would } \\
\text { help me to do my job easily. }\end{array}$ & Sashkin, M. (2013). \\
\hline
\end{tabular}




\section{References}

Allen, T D. Family-Supportive Work Environments: The Role of Organizational Perceptions. Journal of Vocational Behavior. 58; 414-435. http://dx.doi.org/10.1006/jvbe.2000.1774

Armstrong, M. (1995). A handbook of personnel management practices. London: Kogan Page Limited.

Bartel, A. P. (1995). Training, wage growth, and job performance: Evidence from a company database. Journal of Labor Economics, 13(3), 401-425. http://dx.doi.org/10.1086/298380

BOMA. (1988). Office tenant moves and changes. Washington, DC: Building Owners and Managers Association International.

Chin, W. (1998). "Issues and opinions on structural equation modelling”, MIS Quarterly, Vol. 22 No.1, pp. 7-16.

Cheung, C.M.K. and Lee, M.K.O. (2010), "A theoretical model of intentional social action in online social networks", Decision Support Systems, Vol. 49 No.1, pp. 24-30. http://dx.doi.org/10.1016/j.dss.2009.12.006

Delery, J. and Doty, H. 1996. Modes of theorizing in SHRM, Academy of Management Journal, 39(4), 802-835. http://dx.doi.org/10.2307/256713

Dorgan C. E. (1994). Productivity link to the indoor environment estimated relative to ASHRAE 62-1989', Proceedings of Health Buildings'94, Budapest, pp. 461-472.

Elnaga, A. \&Imran, A. (2013). The Effect of Training on Employee Performance. European Journal of Business and Management, 5 (4),137-147

Fornell, C. and Larcker, D.F. (1981), "Evaluating Structural equation models with unobserveable variables and measurement error", Journal of Marketing Research 18 No.1, pp. 39-50. http://dx.doi.org/10.2307/3151312

Goldstein, I. L. (1980). Training in work organizations. Annual Review of Psychology, (31). $229-272$. http://dx.doi.org/10.1146/annurev.ps.31.020180.001305

Hair, J.F., Black, W.C., Babin, B.J. and Anderson, R.E. (2010), Multivariate Data Analaysis, Prentice-Hall, Upper Saddle River, NJ.

Hofstede, G.H. 2005. Culture and Organization (Software of The Mind): Intercultural Cooperation and Its Importance for Survival. McGraw Hill, New York.

Kenney et al. (1992). Management made east. $1^{\text {st }}$ ed. South Carolina: Omron Publishers.

Koentjaraningkrat 2004. Kebudayaan Mentalisas dan Pembangunan. Jakarta: PT. Gramedia Pustaka Utama, Jakarta. (in bahasa)

Mashall Sashkin, William E. Rosenbach (2013). Organization Cultural Assessment Questionaire, International and Pan American.

McCloy, R.A., Campbell J.P., Cudeck R. (1994). A confirmatory test of a model of performance determinants. Journal of Applied Psychology, 79, 493-505. http://dx.doi.org/10.1037/0021-9010.79.4.493

Nickels, W. G., McHugh, J. M., \& McHugh, S. M. (2002). Understanding business (6th ed.). New York, USA: Mc-Graw Hill.

Ninth Malaysia Plan 2006-2010 (2006). Introducing The Motion To Table The Ninth Malaysia Plan, $2006-2010$. Kuala Lumpur:SKMM

Olaniyan, D. A., \& Ojo, L. B. (2008). Staff training and development: A vital tool for organizational effectiveness. European Journal of Scientific Research, 24(3), 326-331.

Ringle, C.M, Wende, S. and Will, A. (2005). "SmartPLS 2.0 (beta)", available at www.smartpls.de (accessed 29 Febreuary 2016).

Sashkin, M., \& Rosenbach, W. E. (1996). Organizational culture assessment questionnaire. Unpublished manuscript, Washington, DC: The George Washington University.

Sekaran, U. \& Bougie, R. (2010). Research methods for business: A skill building approach.United Kingdom: John Wiley \& Son Ltd. 